\title{
Chemical defense of hydrothermal vent and hydrocarbon seep organisms: a preliminary assessment using shallow-water consumers
}

\author{
C. E. Kicklighter ${ }^{1}$, C. R. Fisher ${ }^{2}$, M. E. Hay ${ }^{1, *}$ \\ ${ }^{1}$ School of Biology, Georgia Institute of Technology, Atlanta, Georgia 30332-0230, USA \\ ${ }^{2}$ Department of Biology, 208 Mueller Laboratory, Pennsylvania State University, University Park, Pennsylvania 16802, USA
}

\begin{abstract}
Organisms at deep-sea hydrothermal vent or cold-seep communities represent oases of prey in an otherwise prey-poor desert. Why deep-sea consumers that remove other dense food patches do not rapidly remove the high biomass of prey from these communities is unclear. One potential explanation is that hydrogen sulfide, or other metabolites, in these chemoautotrophic prey could be serving as chemical defenses against generalist consumers; however, neither the palatability of these prey nor their potential defenses have been assessed. We fed tissues from 10 species of deep-sea polychaetes and 2 species of bivalves to shallow-water fishes Fundulus heteroclitus and Leiostomus xanthurus or crabs Callinectes similis and Pachygrapsus crassipes to assess their palatability to generalist consumers. Tissues from 4 polychaetes (Archinome rosacea, Lamellibrachia luymesi, Riftia pachyptila, and Seepiophila jonesi) and 1 bivalve (Calyptogena magnifica) were rejected by some consumers. Blood, which can be sulfide-rich, from R. pachyptila did not deter feeding. Sharp setae deterred feeding on the polychaete $A$. rosacea, while the other unpalatable species produced chemical extracts that deterred feeding. All of the chemically deterrent species contained chemoautotrophic endosymbiotic bacteria, suggesting that these microbial symbionts may produce metabolites that defend their host species. In several instances, consumers encountering novel, deep-sea prey consumed more on the first day of feeding than on later dates, or initially rejected the foods, but then consumed them after repeated encounters. Investigations with predators from the deep-sea are required to more fully understand the ecological role of prey defenses for deep-sea species.
\end{abstract}

KEY WORDS: Chemical defense · Chemical ecology · Cold seeps · Deep-sea · Hydrothermal vents · Tube polychaetes

Resale or republication not permitted without written consent of the publisher

\section{INTRODUCTION}

Antipredator traits, such as chemical and structural defenses, play critical roles in structuring bioticallyrich communities in shallow marine communities (reviews in Hay \& Fenical 1988, 1996, Paul 1992, Paul et al. 2001, Steinberg et al. 1995), but their role in deep-sea cold-seep and hydrothermal vent communities has not been investigated. These deep systems are similar to shallow tropical reefs in that they represent a large mass of biotic resources against a lower resource background and therefore might be subject to heavy impact by generalist consumers. However, little is known about consumer effects on these communities (Tunnicliffe et al. 1990, Micheli et al. 2002, Voight 2000a) and nothing is known about the relative roles of different prey defenses in these habitats. Abiotic factors, such as the chemical speciation of elements, and the extreme and variable nature of these deep communities, have been thought to be the primary factors affecting population and community structure; biotic influences have been assumed to be less important (Tunnicliffe \& Juniper 1990, Shank et al. 1998, Luther et al. 2001). Although biotic interactions have rarely 
been directly addressed in these systems, their importance is beginning to be realized (Tunnicliffe et al. 1990, Mullineaux et al. 2000, MacAvoy et al. 2002, Micheli et al. 2002).

Predatory fishes and crabs are found in high densities around hydrothermal vent (Hessler et al. 1988) and cold-seep communities (MacDonald et al. 1989, MacAvoy et al. 2002). While little is known about deep-sea predator diets, some species are known to consume hydrothermal vent crustaceans (fishes, Micheli et al. 2002), mollusks (octopus, Voight 2000b; fishes, Micheli et al. 2002; crabs, Rhoads et al. 1982, Tunnicliffe \& Jensen 1987), polychaetes (fishes, Rosenblatt \& Cohen 1986, Tunnicliffe et al. 1990; octopus, Voight 2000b; crabs, Desbruyères et al. 1985, Tunnicliffe \& Jensen 1987, Tunnicliffe et al. 1990, Fisher et al. 1994, Micheli et al. 2002), and cold-seep invertebrates (MacAvoy et al. 2002), suggesting that defensive traits could facilitate persistence of common species in these environments.

Some of the most abundant species in these habitats are sedentary polychaetes, some of which acquire energy chemoautotrophically via symbiotic bacteria. To do this they must periodically be exposed to consumers when they emerge from their tubes and use their plumes to absorb hydrogen sulfide and/or oxygen from the surrounding environment. Several species lacking endosymbionts must behave in a similar fashion to absorb oxygen through exposing their gills.

Studies focusing on shallow-water species such as seaweeds, sponges, gorgonians, tunicates, and worms have shown that species that are sedentary, overt, and occur on hard substrates have a high frequency of chemical defenses (Paul 1992, Pawlik et al. 1995, Paul et al. 2001, O'Neal \& Pawlik 2002, Kicklighter 2003). These characteristics (sedentary, overt and occurring on hard substrates) are common for numerous species of deep-sea vent and seep organisms, so these species may also be unpalatable and defended. Because many species from cold seeps and hydrothermal vents commonly have high concentrations of toxic hydrogen sulfide in their tissues, we and others (Arp \& Childress 1983, Childress \& Fisher 1992) have hypothesized that their elevated hydrogen sulfide content would make these prey unpalatable to naive generalist consumers, but this hypothesis has not been tested so far. Because of the logistical difficulties of conducting feeding assays with deep-sea consumers, we fed deep-sea species to generalist fishes and crabs from shallow habitats as a first assessment of prey palatability to generalist consumers. Unpalatable species were then investigated for structural and chemical traits that deterred feeding.

\section{MATERIALS AND METHODS}

Live polychaetes (Lamellibrachia luymesi and Seepiophila jonesi) were collected in July 2001 by the 'Johnson Sea Link I' submersible from hydrocarbon seeps in the Green Canyon Lease Area region (GC 135) of the Gulf of Mexico $\left(27^{\circ} 47^{\prime} \mathrm{N}, 91^{\circ} 30^{\prime} \mathrm{W}\right)$ at a depth of $541 \mathrm{~m}$. All other polychaetes and bivalves were collected in December 2001 by the 'Alvin' submersible at hydrothermal vents near $9^{\circ} 50^{\prime} \mathrm{N}$, $104^{\circ} 17^{\prime} \mathrm{W}$ along the East Pacific Rise at a depth of around $2500 \mathrm{~m}$. All specimens were placed inside a sealed box, brought to the surface, and transferred to a cold room where they were sorted and identified.

To assess polychaete and bivalve palatability, we fed portions of different tissue types from each species to generalist shallow-water predators. Hydrothermal vent species were fed to the shore crab Pachygrapsus crassipes and the fishes mummichog Fundulus heteroclitus and spot Leiostomus xanthurus. Hydrocarbon seep polychaetes were fed to the lesser blue crab Callinectes similis, mummichog and spot. Because hydrocarbon seep and hydrothermal vent organisms were collected at different times, we were not able to feed all prey to the same crab species. Mummichog $(4-6 \mathrm{~cm}$ long), spot (5-8 cm long) and lesser blue crabs $(4-8 \mathrm{~cm}$ carapace width) were collected from Skidaway Island $\left(31^{\circ} 57^{\prime} \mathrm{N}, 81^{\circ} 00^{\prime} \mathrm{W}\right)$ or Little Tybee Island $\left(31^{\circ} 57^{\prime} \mathrm{N}\right.$, $\left.80^{\circ} 56^{\prime} \mathrm{W}\right)$, Georgia. Shore crabs $(3-5 \mathrm{~cm}$ carapace width) were collected from intertidal boulders around Manzanillo, Mexico $\left(19^{\circ} 03^{\prime} \mathrm{N}, 104^{\circ} 20^{\prime} \mathrm{W}\right)$. Mummichog, spot, and the lesser blue crab are shallow-water generalist predators that include invertebrates in their diets (e.g. Chao \& Musick 1977, Baker-Dittus 1978, Hsueh et al. 1992). The shore crab appeared to be a generalist feeder, as it would consume most invertebrates it was offered, and a member of the same genus is known to consume a variety of invertebrates (Cannicci et al. 2002).

We used these consumers for this preliminary assay because of the difficulty of collecting more ecologically appropriate deep-water consumers and maintaining them under conditions in which they feed normally. Many deep-sea consumers appear to be generalists, as they have been observed feeding on a variety of invertebrates (e.g. crab Bythograea thermydron: Van Dover 2000, Micheli et al. 2002) and contain different prey guilds in their guts (e.g. fishes: Micheli et al. 2002; polychaetes, crabs, shrimp, echinoderms: Sokolova 2000 ; octopus: Voight 2000 b). We hoped that our shallow-water generalists might give results typical of other non-specialized consumers from either deep or shallow habitats.

Feeding assays were conducted with fresh tissues on board the RV 'Atlantis' (assays with Pachygrapsus 
crassipes) and with fresh or frozen tissues at the Georgia Institute of Technology's marine facility on Skidaway Island, Georgia (assays with Fundulus heteroclitus, Leiostomus xanthurus and Callinectes similis). Fishes and the lesser blue crab were kept individually in 2.1 or 2.41 containers in recirculating seawater systems. The shore crab was kept in 11 containers, and water was changed daily. To ensure that consumers were not feeding indiscriminately due to unusual hunger levels (Cronin \& Hay 1996), mummichog were fed frozen brine shrimp Artemia sp. (San Francisco Bay Brand), spot were fed brine shrimp sticks (Aquatic Ecosystems), lesser blue crabs were fed chunks of frozen squid, and shore crabs were fed homogenized squid mantle made into squid noodles (see Lindquist \& Hay 1996) to satiation each morning or afternoon. Feeding assays with polychaete or bivalve tissues or extracts were conducted about $1 \mathrm{~h}$ after these feedings.

Our assays followed standard procedures for assessing palatability (e.g. Pawlik et al. 1995, Hay et al. 1998). Consumers initially were offered a palatable control food (same foods as listed above). If this was consumed, each assay individual was offered tissues from a different individual polychaete or bivalve (i.e. despite the difficulty of acquiring deep-sea species, we were able to offer each consumer a bite from a separate prey individual, thus ensuring that all replicates were independent). Most tissues were offered fresh, but specimens from hydrothermal vents on the East Pacific Rise that were fed to mummichog and spot in Georgia were frozen for transport from the RV 'Atlantis'. Any consumer that did not consume either the initial or second control food was excluded from consideration. It was uncommon for the consumer to reject the second control (this occurred for 32 out of 1887 portions offered: $\sim 1.7 \%$ of offerings). For a replicate to be included in the statistical analysis the consumer was required to take the offered tissue into its mouth; this assured an assessment of palatability based on taste as opposed to visual or olfactory discrimination. Thus, replicate individuals that avoided the offering and did not taste it were excluded; this rarely occurred. Because many of the species we obtained were available in only limited numbers, some species were fed to only a subset of consumers.

We frequently offered tissues from polychaetes and bivalves to our fishes and crabs for 2 to 4 consecutive days. Based on tissue availability, each individual consumer within a species was offered portions from a different individual fresh or freshly thawed (hydrothermal vent prey fed to mummichog, spot, and lesser blue crab only) prey individual each day, thus making all replicates independent. We reasoned that it might take more than 1 sampling for the consumers to learn to consume or reject these novel foods, as was demon- strated by Lindquist \& Hay (1995) for a fish (Lagodon rhomboides) offered a chemically defended, but novel, food. Any consumer that rejected the polychaete or bivalve offering was offered a second control food to ensure it did not reject the tissue because it was satiated and not willing to feed on any food.

To determine if rejected tissues were chemicallydefended, crude extracts from the tissues of interest were mixed into a squid-based diet at a natural volumetric concentration (i.e. extract of $1 \mathrm{ml}$ of tissue was mixed into $1 \mathrm{ml}$ of squid food following the method of Lindquist \& Hay 1996) and fed to consumers. Feeding on these treatment foods was compared to feeding on a palatable control consisting of the squid-based food without added extract. The squid-based food was made by reconstituting lyophilized homogenized squid mantle with $0.03 \mathrm{~g}$ sodium alginate $\mathrm{ml}^{-1}$ squid. To incorporate the extracts into the squid paste, an appropriate aliquot of extract was solubilized in ethanol and transferred to a $2.0 \mathrm{ml}$ microcentrifuge tube. Squid paste was then added and mixed to ensure that the extract was evenly dispersed. The squid food was drawn up into a $50 \mu \mathrm{l}$ pipette and extruded into a $0.25 \mathrm{M}$ calcium chloride solution, which caused the squid to harden into a squid 'noodle' that was removed from the calcium chloride and cut into small pieces. Consumption of squid pellets without added extract (but with an equal volume of ethanol added) was compared to that of squid pellets containing extract. These methods have been routinely used to assess the palatability of marine invertebrate extracts (e.g. Pawlik et al. 1995, Lindquist \& Hay 1996, O'Neal \& Pawlik 2002).

Unpalatable tissues were extracted 3 times in a volume of acetone, ethanol or methanol (based on availability) equivalent to approximately 2 times the volume of the tissues. The extract was filtered to remove particulates and the solvent was removed with a rotary evaporator or by blowing a stream of air over the extract. Additional purification of deterrent crude extracts from Seepiophila jonesi and Lamellibrachia luymesi was accomplished by partitioning between 9:1 methanol:water versus hexanes. The hexanes layer was collected, the solvent removed, and the extract bioassayed. The methanol was then removed from the methanol:water fraction using a rotary evaporator and the resulting water was partitioned against ethyl acetate. Bioassays were run separately on the ethyl acetate and water partitions. For $S$. jonesi, only the water fraction was deterrent, so we attempted further separation by reversed-phase chromatography.

Because hydrogen sulfide in some deep-sea hydrothermal vent organisms had been hypothesized to deter consumers (Arp \& Childress 1983, Childress \& Fisher 1992), we also tested the effects of Riftia pachyptila blood (which can contain millimolar concentrations of 
sulfide and is the tissue that is most sulfide-rich: Childress et al. 1984) on feeding. To assay this, we offered consumers either freeze-dried krill (control) or freezedried krill saturated in R. pachyptila blood.

Seepiophila jonesi and Riftia pachyptila obturaculum were unpalatable to mummichog and we suspected this might be due to toughness, as they were difficult to cut. To eliminate structural properties, obturaculum tissues were lyophilized, ground to a fine powder and incorporated into a palatable base of sodium alginate (as a gelling agent). These food pellets, versus a palatable control (squid paste), were fed to fishes. To test the role of Archinome rosacea setae in deterring consumers, we fed Pachygrapsus crassipes polychaete portions that contained these sharp hairs versus polychaete portions from which we had physically removed the setae with forceps.

Fisher's Exact test was used to assess acceptance versus rejection of control foods versus polychaete or bivalve portions, homogenated polychaete or bivalve tissues, and chemical extracts in palatable foods.

\section{RESULTS}

Of 12 species investigated, 5 had at least 1 tissue that was unpalatable to at least 1 of the consumers (Table 1). The trophosomes of both vestimentiferans from hydrocarbon seeps, Seepiophila jonesi and Lamellibrachia luymesi, were unpalatable to the mummichog. In addition, the obturaculum of $S$. jonesi was unpalatable to the mummichog and the trophosome was also unpalatable to the lesser blue crab (Table 1). In all of these cases, significant rejection occurred on the second, but not the first, day of feeding. For the hydrothermal vent vestimentiferan, Riftia pachyptila, the trophosome was unpalatable to the shore crab and spot (Table 1). For the shore crab, this occurred on Days 3 and 4 of feeding, but not on Days 1 or 2. Spot consistently rejected $R$. pachyptila trophosome (Days 1 through 2) but rejection was even greater (although not statistically) on Days 2 and 3 (11 and 18\% accepted respectively) than on Day 1 (50\% accepted). In addition, R. pachyptila obturaculum, plume filaments, and vestimentum were unpalatable to the shore crab once out of 4 days tested, but the temporal patterns of this rejection were variable (Table 1). The obturaculum was unpalatable to the mummichog on the one occasion it was tested. In addition, the gill of the hydrothermal vent clam Calyptogena magnifica was unpalatable to the shore crab but not to the fishes (Table 1), as was the hydrothermal vent annelid Archinome rosacea on the single day it was tested. Given that Table 1 shows 150 separate assays, 7 to 8 assays with a p-value of 0.05 could be expected from chance alone (we detected 15 significant differences). Thus, we suggest that more emphasis be placed on those assays with lower $p$-values $(p \leq 0.01$ : where chance should have produced only 1.5 significant differences, we detected 9), or those showing considerable consistency (e.g. R. pachyptila trophosome).

Freeze-dried krill saturated with Riftia pachyptila blood were readily eaten by the shore crab and mummichog on the 3 consecutive days they were offered (Table 1), suggesting that the blood, which can commonly contain high concentrations of sulfide, does not deter feeding. In contrast, the crude extract from $R$. pachyptila trophosome was unpalatable to the shore crab, but this extract did not deter the spot or mummichog (Fig. 1A-C). In addition, crude extract from Calyptogena magnifica gill was unpalatable to the shore crab (Fig. 1A). Seepiophila jonesi trophosome crude extract was unpalatable to the mummichog and the lesser blue crab (Fig. 1C,D); further purification of this extract produced a water-soluble fraction that deterred the lesser blue crab (Fig. 1F), but all fractions were palatable to the mummichog (Fig. 1E). We used reversed-phase chromatography to further separate the water-soluble fraction, but deterrence was lost following this procedure. Lamellibrachia luymesi trophosome crude extract was deterrent to the mummichog (Fig. 1C), but further separation of the crude extract by liquid-liquid partition resulted in loss of deterrence.

When we offered homogenated Riftia pachyptila and Seepiophila jonesi obturaculum to the mummichog, tissue homogenates were palatable, suggesting that toughness could have played a role in their rejection: $100 \%$ consumed for both controls and tissues from each species, $\mathrm{n}=10$ ( $S$. jonesi obturaculum) and $\mathrm{n}=13$ R. pachyptila obturaculum), $\mathrm{p}>0.99$ for each. We were unable to bioassay homogenated tissues of Archinome rosacea, as we could not lyophilize tissues on board the RV 'Atlantis'. However, when A. rosacea portions with and without setae removed were fed to Pachygrapsus crassipes, removal of setae significantly increased palatability (9 of 10 were eaten following removal of setae; 2 of 10 were eaten with intact setae; $\mathrm{p}=0.006$, Fisher's Exact test).

\section{DISCUSSION}

Of the 12 species investigated, 5 (Archinome rosacea, Calyptogena magnifica, Lamellibrachia luymesi, Riftia pachyptila and Seepiophila jonesi) had tissues that were unpalatable to 1 or more of our consumers (Table 1). Of the 5 unpalatable tissues, 4 contained chemoautotrophic endosymbiotic bacteria (C. magnifica gill and L. luymesi, R. pachyptila and 
Table 1. Palatability to shore crab Pachygrapsus crassipes, mummichog Fundulus heteroclitus, spot Leiostomus xanthurus and lesser blue crab Callinectes similis of polychaetes and bivalves from hydrocarbon seeps and hydrothermal vents. Percent of polychaete or bivalve portions consumed by each predator (control was always $100 \%$ consumed). Number in parentheses: sample size. Deterrent effects in bold face (Fisher's Exact test)

\begin{tabular}{|c|c|c|c|c|}
\hline \multirow[t]{2}{*}{ Prey species } & \multirow[b]{2}{*}{ Shore crab } & \multirow{2}{*}{$\begin{array}{l}\text { Con } \\
\text { Mummichog }\end{array}$} & \multirow[b]{2}{*}{ Spot } & \multirow[b]{2}{*}{ Lesser blue crab } \\
\hline & & & & \\
\hline \multicolumn{5}{|l|}{ Seepiophila jonesi } \\
\hline Day 1 & & $75(8)$ & $78(9)$ & $100(8)$ \\
\hline Day 2 & & 55 (11) $p<0.04$ & $71(7)$ & $100(8)$ \\
\hline \multicolumn{5}{|l|}{ Vestimentum } \\
\hline Day 1 & & $100(8)$ & $100(8)$ & $100(9)$ \\
\hline Day 2 & & $70(10)$ & $100(8)$ & $100(9)$ \\
\hline \multicolumn{5}{|l|}{ Trophosome } \\
\hline Day 1 & & $88(8)$ & $100(9)$ & $100(9)$ \\
\hline Day 2 & & $44(9) \mathrm{p}<0.03$ & $100(7)$ & $50(10) \mathrm{p}<0.04$ \\
\hline \multicolumn{5}{|c|}{ Lamellibrachia luymesi } \\
\hline \multicolumn{5}{|c|}{ Plume filaments } \\
\hline Day 1 & & $88(8)$ & $100(8)$ & $100(8)$ \\
\hline Day 2 & & $75(8)$ & $100(8)$ & $100(8)$ \\
\hline \multicolumn{5}{|l|}{ Vestimentum } \\
\hline Day 1 & & $100(8)$ & $100(8)$ & $100(8)$ \\
\hline Day 2 & & $100(8)$ & $100(8)$ & $100(8)$ \\
\hline \multicolumn{5}{|l|}{ Trophosome } \\
\hline Day 1 & & $67(9)$ & $100(8)$ & $100(7)$ \\
\hline Day 2 & & 45 (11) $p<0.01$ & $100(8)$ & $100(8)$ \\
\hline \multicolumn{5}{|l|}{ Alvinella caudata } \\
\hline Branchiae & $100(10)$ & & & \\
\hline Body & $100(10)$ & & & \\
\hline \multicolumn{5}{|l|}{ Alvinella pompejana } \\
\hline \multicolumn{5}{|l|}{ Tentacles } \\
\hline Day 1 & $100(6)$ & & & \\
\hline Day 2 & $100(5)$ & & & \\
\hline \multicolumn{5}{|l|}{ Branchiae } \\
\hline Day 1 & $90(10)$ & $100(10)$ & $100(12)$ & \\
\hline Day 2 & $90(10)$ & & & \\
\hline Day 3 & $100(7)$ & & & \\
\hline \multicolumn{5}{|l|}{ Body } \\
\hline Day 1 & $90(10)$ & $100(10)$ & $100(12)$ & \\
\hline Day 2 & $80(10)$ & & & \\
\hline Day 3 & $100(13)$ & & & \\
\hline Archinome rosacea & $20(10) p<0.001$ & $50(8)$ & $78(9)$ & \\
\hline Branchipolynoe sp. & $67(6)$ & $75(12)$ & $100(12)$ & \\
\hline \multicolumn{5}{|c|}{ Golopogmystides aristata } \\
\hline Day 1 & $100(10)$ & $80(10)$ & $100(10)$ & \\
\hline Day 2 & $93(15)$ & & & \\
\hline \multicolumn{5}{|l|}{ Hesiolyra bergi } \\
\hline Day 1 & $100(10)$ & $100(10)$ & $80(10)$ & \\
\hline Day 2 & $100(10)$ & & & \\
\hline Paralvinella grasslei & & & & \\
\hline Branchiae & & & & \\
\hline Day 1 & $90(10)$ & $75(12)$ & $100(14)$ & \\
\hline Day 2 & $91(11)$ & $83(12)$ & $100(13)$ & \\
\hline Day 3 & 89 (18) & $91(11)$ & $100(13)$ & \\
\hline Body & & & & \\
\hline Day 1 & $100(10)$ & $100(10)$ & $100(14)$ & \\
\hline Day 2 & $100(10)$ & $100(10)$ & $100(13)$ & \\
\hline Day 3 & $100(18)$ & $100(11)$ & $100(14)$ & \\
\hline
\end{tabular}


Table 1 (continued)

\begin{tabular}{|c|c|c|c|c|}
\hline \multirow[t]{2}{*}{ Prey species } & \multirow[b]{2}{*}{ Shore crab } & \multirow{2}{*}{\multicolumn{2}{|c|}{$\begin{array}{l}\text { Consumer } \\
\text { Mummichog }\end{array}$}} & \multirow[b]{2}{*}{ Lesser blue crab } \\
\hline & & & & \\
\hline \multicolumn{5}{|c|}{ Riftia pachyptila } \\
\hline \multicolumn{5}{|c|}{ Obturaculum } \\
\hline Day 1 & $70(10)$ & $47(19) p<0.001$ & $100(14)$ & \\
\hline Day 2 & $100(18)$ & & $100(13)$ & \\
\hline Day 3 & $44(16) p<0.001$ & & 93 (14) & \\
\hline Day 4 & $91(22)$ & & & \\
\hline \multicolumn{5}{|c|}{ Plume filaments } \\
\hline Day 1 & $50(10) \mathrm{p}<0.05$ & & & \\
\hline Day 2 & $100(18)$ & & & \\
\hline Day 3 & 75 (16) & & & \\
\hline Day 4 & $100(22)$ & & & \\
\hline \multicolumn{5}{|c|}{ Vestimentum } \\
\hline Day 1 & $50(10) p<0.05$ & $72(18)$ & $100(13)$ & \\
\hline Day 2 & 94 (18) & 88 (16) & $100(13)$ & \\
\hline Day 3 & $69(16)$ & & $92(13)$ & \\
\hline Day 4 & $87(23)$ & & & \\
\hline \multicolumn{5}{|l|}{ Trophosome } \\
\hline Day 1 & $100(10)$ & 79 (19) & $50(14) p<0.01$ & \\
\hline Day 2 & $89(10)$ & 85 (13) & 11 (9) $p<0.001$ & \\
\hline Day 3 & $63(16) p<0.05$ & $69(13)$ & $18(11) p<0.001$ & \\
\hline Day 4 & $55(22) p<0.001$ & & & \\
\hline \multicolumn{5}{|l|}{ Blood } \\
\hline Day 1 & $83(23)$ & $100(9)$ & & \\
\hline Day 2 & $96(23)$ & $100(10)$ & & \\
\hline Day 3 & $100(22)$ & $100(10)$ & & \\
\hline \multicolumn{5}{|c|}{ Bathymodiolus thermophilus } \\
\hline \multicolumn{5}{|c|}{ Mantle } \\
\hline Day 1 & $100(20)$ & $100(10)$ & $100(10)$ & \\
\hline Day 2 & $100(20)$ & $100(10)$ & $100(11)$ & \\
\hline Day 3 & $95(20)$ & $100(10)$ & $91(11)$ & \\
\hline Day 4 & $95(20)$ & & & \\
\hline \multicolumn{5}{|l|}{ Gill } \\
\hline Day 1 & $95(20)$ & $100(10)$ & $100(10)$ & \\
\hline Day 2 & $100(20)$ & $100(10)$ & $100(10)$ & \\
\hline Day 3 & $100(20)$ & $90(10)$ & $100(10)$ & \\
\hline Day 4 & $100(20)$ & & & \\
\hline \multicolumn{5}{|c|}{ Calyptogena magnifica } \\
\hline \multicolumn{5}{|l|}{ Mantle } \\
\hline Day 1 & $100(14)$ & $100(10)$ & $100(10)$ & \\
\hline Day 2 & $100(14)$ & $100(11)$ & $100(9)$ & \\
\hline \multicolumn{5}{|l|}{ Gill } \\
\hline Day 1 & $36(14) p<0.001$ & $100(10)$ & $100(10)$ & \\
\hline Day 2 & & $91(11)$ & $100(10)$ & \\
\hline
\end{tabular}

$S$. jonesi trophosome). This suggests that these bacterial symbionts may not only provide their host with novel access to chemoautotrophic production, but could also produce metabolites that defend the host (see Gil-Turnes et al. 1989 and Bewley et al. 1996 for similar examples for shallow-water species). Gill tissue of the mussel Bathymodiolus thermophilus also hosts endosymbiotic bacteria, but this tissue was consistently palatable, showing that not all of these microbes are associated with defended tissues.
The hydrogen sulfide present in vestimentiferan tube worms has been postulated to deter consumers (Arp \& Childress 1983). However, Riftia pachyptila blood did not deter any consumer in our assays. Because we could not measure sulfide levels on board ship, we used blood only from $R$. pachyptila individuals with bright green, rather than dark or black trophosomes (the green coloration indicates high levels of elemental sulfur: C. R. Fisher pers. obs.). Bacteria deposit sulfur when sulfide is available to them (Vetter 
1985, Childress et al. 1991a,b), suggesting that high elemental sulfur could be an indication of high sulfide content. Thus, the treatment foods we offered to the shore crab were potentially high in sulfide (millimolar concentrations: Childress et al. 1984). Pawlik et al. (2002) also found that sulfidic compounds were ineffective defenses in shallow communities. They noted that a natural mixture of sponge compounds, including methyl isothiocyanate (a sulfidic volatile) and dimethyl sulfide (at concentrations up to 100 times those found in a sponge) were palatable to a tropical reef fish (Thalassoma bifasciatum).

If hydrogen sulfide were responsible for the deterrence we observed, we would expect trophosomes from different polychaetes and from the hydrothermal vent clam to be similarly unpalatable; this was not the case (Table 1). Consumers varied considerably in their feeding on these hydrogen-sulfide-containing tissues. Furthermore, the gill of the mussel Bathymodiolus thermophilus (which also contains bacterial endosymbionts) was palatable to every consumer tested and was readily eaten for 4 consecutive days by the shore crab. This difference may be due to the fact that mussel gill symbionts are physiologically different from clam gill and trophosome symbionts and could thus be producing different (possibly defensive) metabolites. Clam gill and trophosome symbionts both utilize sulfide as an energy source, while mussel gill symbionts only utilize thiosulfate and do not accumulate elemental sulfur (reviewed by Childress \& Fisher 1992 and by Nelson \& Fisher 1995). Another possibility for the variation in palatability of these endosymbiotic tissues is that type of symbionts varies among species (Edwards \& Nelson 1991, Distel 1998).

Although hydrogen sulfide did not appear to deter consumers, the rejection of polychaete trophosomes and clam gill by some consumers was clearly chemicallymediated. Crude extracts from these 4 endosymbiont-containing tissues were unpalatable to at least 1 consumer (Fig. 1). Further purification of crude extracts from most tissues was either not possible (due to lack of chemistry facilities) or was unsuccessful because the activity was lost follow-
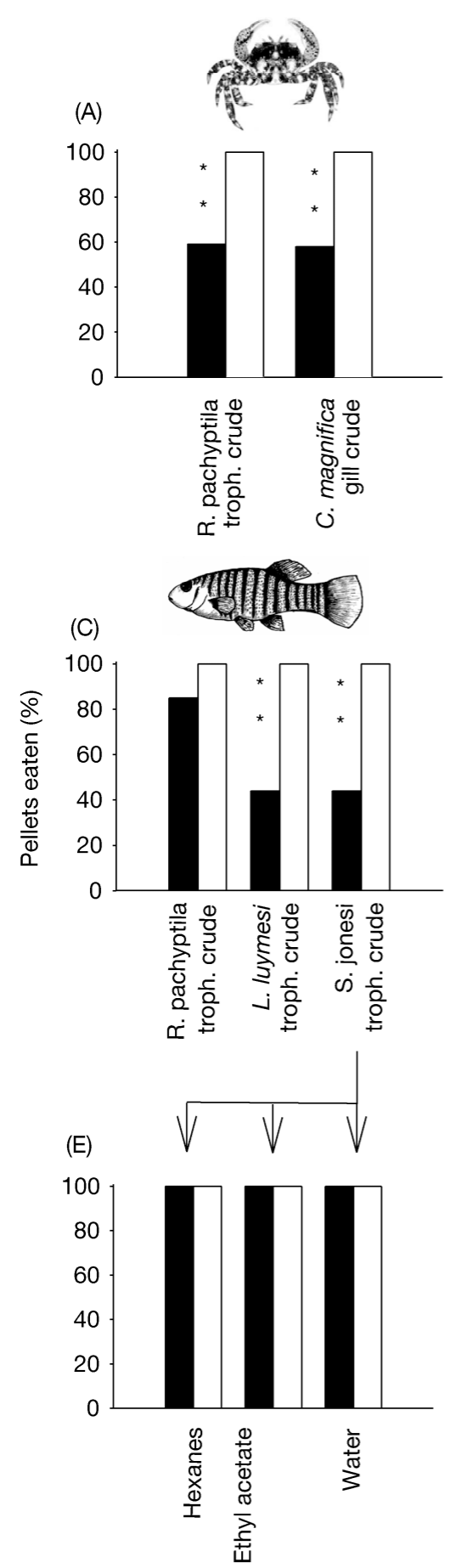

Control
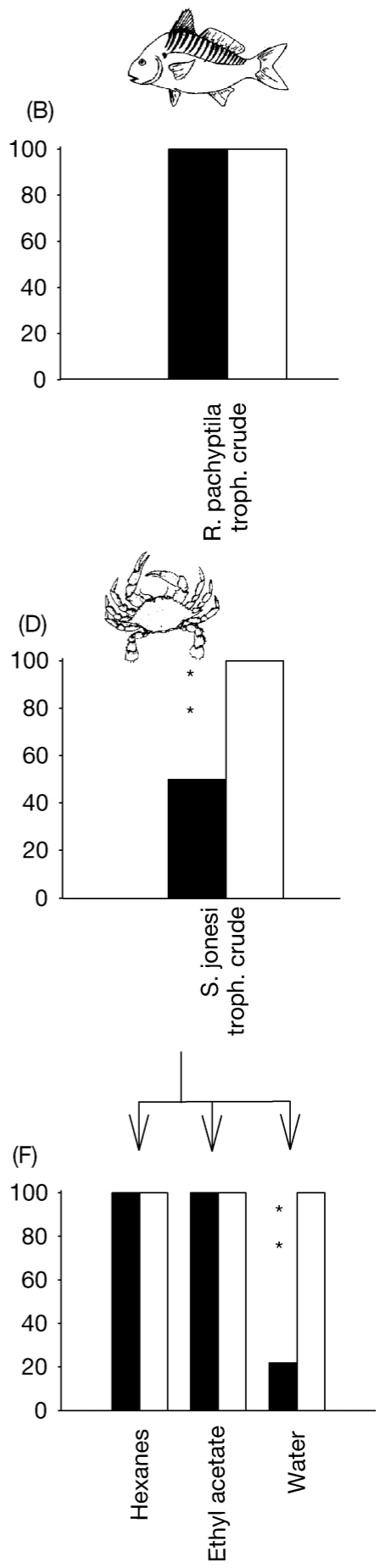

Extract $n=8-12$
Fig. 1. Palatability of polychaetes (Lamellibrachia luymesi, Riftia pachyptila and Seepiophila jonesi) and clam (Calyptogena magnifica) extracts to crabs and fishes. Percent eaten by (A) shore crab Pachygrapsus crassipes, (B) spot Leiostomus xanthurus, (C) mummichog Fundulus heteroclitus and (D) lesser blue crab Callinectes similis. (E,F) Fractions in deterrent crude extracts of $S$. jonesi trophosome (troph. crude) fed to (E) mummichog (in squid pellets) in (C), and to (F) lesser blue crab in (D). ${ }^{* *} \mathrm{p}<0.01$

(Fisher's Exact test) 
ing multiple separation procedures. These problems suggested that the deterrent metabolites could be volatile or unstable. We were, however, able to demonstrate that the trophosome of Seepiophila jonesi contains feeding deterrents that are water-soluble (Fig. 1F).

In some cases, tissue rejection appeared to be based on structural rather than chemical traits. When we physically removed the sharp setae from Archinome rosacea, portions without setae were readily eaten. Also, when we destroyed the structure and toughness of obturaculums from Riftia pachyptila and Seepiophila jonesi by freeze-drying, grinding, and making the powdered tissue into a food paste, these foods were readily consumed. This suggests that toughness may have been responsible for rejection of these tissues, but it is also possible that lyophilization degraded deterrent chemicals.

Unlike patterns of palatability for shallow-water species (Kicklighter 2003, Kicklighter et al. 2003), many of the chemically deterrent tissues of the deepsea polychaetes we investigated are not normally exposed to predators because they are protected inside a tough, chitinous tube, which, in some species (Lamellibrachia luymesi and Seepiophila jonesi), is often partially buried beneath the sediment. Thus, unpalatability could be a serendipitous effect of some other factors (e.g. pathogen resistance) that select for the chemical properties. While Calyptogena magnifica is enclosed inside a thick shell, it gapes open, and thus a chemically defended gill might be less vulnerable to consumers and an adaptive advantage for this species.

The only study to examine feeding preferences of naturally occurring deep-sea consumers (Micheli et al. 2002) did observe consumption of prey at a hydrothermal vent. When the vestimentiferan polychaete Riftia pachyptila, the mussel Bathymodiolus thermophilus and the limpet Lepitodrilus elevatus were set on the seafloor near well-established vent communities, the crabs Bythograea thermydron and Munidopsis subsquamosa and the whelk Phymorhynchus starmeri fed on these prey. It is not known, however, if certain body parts, such as the trophosome or gill, were avoided. $B$. thermydron has been observed to feed on the obturaculum and plume filaments of $R$. pachyptila, but has not been observed feeding on the trophosome (C. E. Kicklighter pers. obs.). Both hydrothermal vent and cold-seep communities represent a large biomass of potential prey within a larger habitat where food resources are scarce. Thus, we might expect consumers to recruit to and exploit the biotic resources of these communities, possibly selecting for defenses of potential prey.

Herein, we have presented evidence of rejection of some deep-sea prey tissues by naive shallow-water consumers that are generalist feeders. While hydrogen sulfide has been hypothesized to act as a predator deterrent, the blood of Riftia pachyptila (which we expected to have the highest concentration of hydrogen sulfide, but whose concentration we did not measure directly) did not deter feeding by the generalist consumers we assayed. Instead, the distastefulness of several tissues containing endosymbiotic bacteria seem to be due to other chemical deterrents, possibly produced by the bacteria. Thus, the microbe-host associations that allow unique, chemoautotrophic production in the deep sea may also serve a second function as producers of metabolites that defend the host and its associates.

Acknowledgements. We would like to thank E. Cordes and P. Sobecky for providing hydrocarbon seep polychaete collections, S. Carney, S. Dattagupta, B. Govenar, and T. Waltz for help with sorting hydrothermal vent collections, and C. Van Dover for providing mussel collections. H. Mills provided information on the cold-seep collection site; S. Hourdez helped with polychaete identifications. We are grateful to the pilots and crew of the 'Alvin' group and to the crew of the RV 'Atlantis' for their cooperation. Funding was provided by an NSF predoctoral fellowship and IGERT award to C.E.K., the Harry and Linda Teasley Endowment to the Georgia Institute of Technology, and by NSF OCE-0002729 to C.R.F.

\section{LITERATURE CITED}

Arp A, Childress J (1983) Sulfide binding by the blood of the hydrothermal vent tube worm Riftia pachyptila. Science 219:295-297

Baker-Dittus AM (1978) Foraging patterns of three sympatric killifish. Copeia 3:383-389

Bewley CA, Holland ND, Faulkner DJ (1996) Two classes of metabolites from Theonella swinhoei are localized in distinct populations of bacterial symbionts. Experientia 52: 716-722

Cannicci S, Gomei M, Boddi B, Vannini M (2002) Feeding habits and natural diet of the intertidal crab Pachygrapsus marmoratus: opportunistic browser or selective feeder? Estuar Coast Shelf Sci 54:983-1001

Chao LN, Musick JA (1977) Life history, feeding habits and functional morphology of juvenile sciaenid fishes in the York River estuary, Virginia. Natl Mar Fish Serv US 75:657-702

Childress J, Fisher C (1992) The biology of hydrothermal vent animals: physiology, biochemistry and autotrophic symbioses. Oceanogr Mar Biol Annu Rev 30:337-441

Childress JJ, Arp AJ, Fisher CR (1984) Metabolic and blood characteristics of the hydrothermal vent tube-worm Riftia pachyptila. Mar Biol 83:109-124

Childress JJ, Fisher CR, Favuzzi JA, Kochevar R, Sanders NK, Alayse AM (1991a) Sulfide-driven autotrophic balance in the bacterial symbiont-containing hydrothermal vent tubeworm Riftia pachyptila, Jones. Biol Bull (Woods Hole) 180:135-153

Childress JJ, Fisher CR, Favuzzi JA, Sanders NK (1991b) Sulfide and carbon dioxide uptake by the hydrothermal vent clam, Calyptogena magnifica and its chemoautotrophic symbionts. Physiol Zool 64:1444-1470

Cronin G, Hay ME (1996) Within-plant variation in seaweed palatability and chemical defenses: optimal defense 
theory versus the growth-differentiation balance hypothesis. Oecologia 105:361-368

Desbruyères D, Gaill F, Laubier L, Fouquet Y (1985) Polychaetous annelids from hydrothermal vent ecosystems: an ecological overview. Bull Biol Soc Wash 6:103-116

Distel D (1998) Evolution of chemoautotrophic endosymbioses in bivalves. Bioscience 48:277-286

Edwards D, Nelson D (1991) DNA-DNA-solution hybridization studies of the bacterial symbionts of hydrothermal vent tube worms (Riftia pachyptila and Tevnia jerichonana). Appl Environ Microbiol 57:1082-1088

Fisher CR, Childress JJ, Macko S, Brooks J (1994) Nutritional interactions in Galapagos Rift hydrothermal vent communities: inferences from stable carbon and nitrogen isotope analyses. Mar Ecol Prog Ser 103:45-55

Gil-Turnes MS, Hay ME, Fenical W (1989) Symbiotic marine bacteria chemically defend crustacean embryos from a pathogenic fungus. Science 246:116-118

Hay ME, Fenical W (1988) Marine plant-herbivore interactions - the ecology of chemical defense. Annu Rev Ecol Syst 19:111-145

Hay ME, Fenical W (1996) Chemical ecology and marine biodiversity: Insights and products from the sea. Oceanography 9:10-20

Hay M, Stachowicz J, Cruz-Rivera E, Bullard S, Deal M, Lindquist $N$ (1998) Bioassays with marine and freshwater macroorganisms. In: Haynes K, Millar J (eds) Methods in chemical ecology, Vol 2. Chapman \& Hall, New York, p 39-141

Hessler R, Smithey W, Boudrias M, Keller C, Lutz R, Childress $\mathrm{J}$ (1988) Temporal change in megafauna at the Rose Garden hydrothermal vent (Galapagos Rift: eastern tropical Pacific). Deep-Sea Res 35:1681-1709

Hsueh P, McClintock JB, Hopkins TS (1992) Comparative study of the diets of the blue crabs Callinectes similis and C. sapidus from a mud-bottom habitat in Mobile Bay, Alabama. J Crustac Biol 12:615-619

Kicklighter CE (2003) Antipredation strategies in marine worms: geographic, ecological, and taxonomic patterns. $\mathrm{PhD}$ thesis, Georgia Institute of Technology, Atlanta

Kicklighter CE, Kubanek J, Barsby T, Hay ME (2003) Palatability and defense of some tropical infaunal worms: alkylpyrrole sulfamates as deterrents to fish feeding. Mar Ecol Prog Ser 263:299-306

Lindquist N, Hay ME (1995) Can small rare prey be chemically defended? The case for marine larvae. Ecology 76 : $1347-1358$

Lindquist N, Hay ME (1996) Palatability and chemical defense of marine larvae. Ecol Monogr 66:431-450

Luther G, Rozan T, Taillefert M, Nuzzio D, Meo CD, Shank T, Lutz R, Cary S (2001) Chemical speciation drives hydrothermal vent ecology. Nature 410:813-816

MacAvoy S, Carney R, Fisher C, Macko S (2002) Use of chemosynthetic biomass by large, mobile, benthic predators in the Gulf of Mexico. Mar Ecol Prog Ser 225:65-78

MacDonald IR, Boland GS, Baker JS, Brooks JM, Kennicutt MG III, Bidigare RR (1989) Gulf of Mexico hydrocarbon seep communities. II. Spatial distribution of seep organisms and hydrocarbons at Bush Hill. Mar Biol 101:235-247

Micheli F, Peterson C, Mullineaux L, Fisher C, Mills S, Sancho G, Johnson G, Lenihan H (2002) Predation structures communities at deep-sea hydrothermal vents. Ecol Monogr 72: $365-382$

Editorial responsibility: Lisa Levin (Contributing Editor), La Jolla, California, USA
Mullineaux L, Fisher C, Peterson C, Schaeffer S (2000) Tubeworm succession at hydrothermal vents: use of biogenic cues to reduce habitat selection error? Oecologia 123: 275-284

Nelson D, Fisher C (1995) Chemoautotrophic and methanotrophic endosymbiotic bacteria at vents and seeps. In: Karl D (ed) Microbiology of deep-sea hydrothermal vent habitats. CRC Press, Boca Raton, FL, p 125-167

O'Neal W, Pawlik JR (2002) A reappraisal of the chemical and physical defenses of Caribbean gorgonian corals against predatory fishes. Mar Ecol Prog Ser 240:117-126

Paul V (1992) Ecological roles of marine natural products. Comstock Publishing Associates, Ithaca, NY

Paul VJ, Cruz-Rivera E, Thacker RW (2001) Chemical mediation of macroalgal-herbivore interactions: ecological and evolutionary perspectives. In: McClintock JB, Baker BJ (eds) Marine chemical ecology. CRC Press, Boca Raton, FL, p 227-266

Pawlik JR, Chanas B, Toonen R J, Fenical W (1995) Defenses of Caribbean sponges against predatory reef fish. I. Chemical deterrency. Mar Ecol Prog Ser 127:183-194

Pawlik JR, McFall G, Zea S (2002) Does the odor from sponges of the genus Ircinia protect them from fish predators? J Chem Ecol 28:1103-1115

Rhoads DC, Lutz RA, Cerrato RM, Revelas EC (1982) Growth and predation activity at deep-sea hydrothermal vents along the Galapagos Rift. J Mar Res 40:503-516

Rosenblatt R, Cohen DM (1986) Fishes living in deep sea thermal vents in the tropical eastern Pacific, with descriptions of a new genus and two new species of eelpouts (Zoarcidae). Trans S Diego Soc Nat His 21:71-79

Shank TM, Fornari DJ, Von Damm KL, Lilley MD, Haymon RM, Lutz RA (1998) Temporal and spatial patterns of biological community development at nascent deep-sea hydrothermal vents ( $9^{\circ} 50^{\prime} \mathrm{N}$, East Pacific Rise). Deep-Sea Res II 45:465-471

Sokolova MN (2000) Feeding and trophic structure of the deep-sea macrobenthos. Science Publishers, Enfield, NH

Steinberg PD, Estes JA, Winter FC (1995) Evolutionary consequences of food chain length in kelp forest communities. Proc Natl Acad Sci USA 92:8145-8148

Tunnicliffe V, Jensen RG (1987) Distribution and behaviour of the spider crab Macroregonia macrochira Sakai (Brachyura) around the hydrothermal vents of the northeast Pacific. Can J Zool 65:2443-2449

Tunnicliffe V, Juniper S (1990) Dynamic character of the hydrothermal vent habitat and the nature of sulfide chimney fauna. Prog Oceanogr 24:1-13

Tunnicliffe V, Garrett J, Johnson HP (1990) Physical and biological factors affecting the behaviour and mortality of hydrothermal vent tubeworms (vestimentiferans). DeepSea Res 37:103-125

Van Dover CV (2000) The ecology of deep-sea hydrothermal vents. Princeton University Press, Princeton, NJ

Vetter RD (1985) Elemental sulfur in the gills of three species of clams containing chemoautotrophic symbiotic bacteria: a possible inorganic energy storage compound. Mar Biol 88:33-42

Voight JR (2000a) A review of predators and predation at deep-sea hydrothermal vents. Cah Biol Mar 41:155-166

Voight JR (2000b) A deep-sea octopus (Graneledone cf. boreopacifica) as a shell-crushing hydrothermal vent predator. J Zool 252:335-341

Submitted: July 21, 2003; Accepted: March 9, 2004

Proofs received from author(s): June 21, 2004 